\title{
Earned Value Management (EVM) on Controlling the Implementation of the Road Construction Project
}

\author{
Latupeirissa Josefine Ernestine
}

\begin{abstract}
Road infrastructure development projects that are being developed in East Indonesia, one of which is located on the district of West Southeast Maluku in Maluku province. Deviation from the time of execution, on project to improve the Trans Yamdena Tumbur road on West Southeast Maluku District in 2013 the background of this study, which aims to determine the results of the performance of the project and the cause of the deviation as well as how to control. Evaluation of the performance time and cost in this study as well as control were analyzed using Earned Value Management (EVM) concept. The results evaluation showed that there are deviations from the schedule of implementation resulting in delayed projects in total for approximately 14 working days. This is caused by the redesign process of planning for one week at the 1st week which result in decreased performance on 2nd week. While the reduction in the number of workers began at 12 th week, resulting in decreased performance at 13th week until the completion of the project. Control of the deviation of project time can be done by accelerating time to redesign at 1 st week and increase the amount of labor as before began at 12th week. Based on the results of the control, the project is estimated to be completed in its entirety for approximately 14 weeks or faster 2 weeks of 16-week duration of the plan Thus it is estimated the actual cost savings may occur in aggregate approximately $10.55 \%$ of the actual cost that has been realized. It becomes recommendations to implementing similar projects with project site approximately the same in the implementation of road projects in the future.
\end{abstract}

Keywords- Earned Value Management (EVM), Deviation Implementation Schedule, Control

\section{Introduction}

The successful implementation of an infrastructure project of road infrastructure in particular is how its output as planned either in physical form as well as the readiness to operate as they are functional. Construction of road infrastructure and the development of eastern Indonesia, especially in the Moluccas become a government priority this year and next year. Completion of the implementation of road construction in this area are often not in accordance with the planning, this can be caused by several things that can be controlled or not controlled by the project management, Road improvements in the area of West Southeast Maluku, especially on the Trans Yamdena Tumbur in 2013 is one of the government programs to accelerate development in the region.

Latupeirissa Josefine Ernestine

Universitas Kristen Indonesia Paulus

Makassar- South Sulawesi - Indonesia
In a previous study conducted by Tayl (2014), only evaluates the performance of the project over a period of two months in which there are deviations from the plan period.This can have an impact on the cost of which has been planned.Therefore it is necessary to do research on the causes of the deviation so it can be given a solution how to control it.

\section{Road Construction Project Implementation and Control Methods}

The construction of the road as required by technical specifications, should be conducted in accordance sequence or stages of work right so the work is more effective and can increase the efficiency of the implementation, it is likely to reduce construction costs and can finish all the work on time. The construction of roads is generally based on the flowchart (flow chart) corresponding technical demands, the types and kinds of work in sequence to achieve the overall goal of project completion. In the course of its implementation are small activities that are part of the main activities which should be implemented at the same time. In addition, the use of equipment in accordance with the correct method, as well as mastery of detail throughout the equipment used to optimize the use of such equipment in order to increase production.

\section{A. Road Improvement of the Trans Yamdena Tumbur}

Construction of road improvements in the area of West Southeast Maluku, especially on the Trans Yamdena -Tumbur in 2013 is one of the government programs to accelerate development in the region. Research by Tayl (2014) is to evaluate the performance of the project over a period of two months. Research results show that the project is experiencing irregularities against time caused by several factors. To analyze how should the performance of the construction of the project can be realized according to plan, and based on the data irregularities that have occurred to conduct further research to determine the causes of the deviation of the time as well as how to control using EVM. 


\section{B. The delay in the implementation of development and improvement of road construction projects}

Completion of the project which is slower than the time that has been planned can be caused by conditions of uncertainty both from external projects, internal projects, as well as of the parties involved. An important parameter in the implementation of the road construction project, which is often used as a target of the project is the budget, schedule, and quality. Success in carrying out the project on time, cost, and quality that has been planned is one of the most important goals for the owner and the contractor. Implementation of the project which is not in accordance with the plan, may result in project delays. Delays in project completion can result in losses for the owner and the contractor. For contractors, delays in addition can lead to cost overrun due to the increase in the project implementation time, can also lead to decline in the credibility of the contractor for the future. As for the owner, delay in operation way for the benefit of society. It can also lead to disputes and claims between the owner and the contractor.

\section{Earned Value Management}

In addition to planning, one of the functions that greatly affect the outcome of the project is the control function which achievement of the targets is not enough simply to the organization and leadership of a reliable and high working motivation, but the supervision and control is an integral and integrated. The purpose of monitoring and control is to monitor, assess and even held correction and guidance so that a predetermined can be accomplished in accordance with planning

One method that has been widely applied in the International company is Earned Value concept as applied to Calofornia Department of Transportation, US Department of Energy and NASA. Meanwhile, the American National Standard Institute (ANSI) has published ANSI / 748 which is a standard application of Earned Value Management System in the management of the project.These systems incorporate and link the elements of the budget, expenses, schedule, score result, the scope of work and implementing organizations, which are summarized in a procedure, with some aspects and criteria that must be met. This indicates that the Earned Value Management System is very necessary to be applied in the management of the project as an integrated activity between the policies, procedures and practices in decision making.

According to the national industry standard in the United States (1998) is an American National Standards Institute / Electronic Industries Alliance (ANSI / EIA) 748 - A - 1998, in application of the concept of Earned Value, there are five major aspects of project management, which translated into 32 criteria. The five aspects are: 1). Organization, 2). Planning, scheduling, and budgeting, 3). Accounting system, 4). Analysis and management reports and 5). Revision and repair data.

\section{Research Methods}

The primary data and secondary data on one of the projects that the Government of Works Maintenance / improvement of the Trans Yamdena-Tumbur where there are deviations to schedule the execution time plan. Secondary data include contract documents and reports on implementation while the primary data are interviews with the parties directly involved in the project.

Occupation is Heaps subgrade and pavement improvement with Penetration Macadam layer along the $3 \mathrm{~km}$.

The contract is dated July 13, 2013 with the duration of the project plan: \pm 120 working days / 16 weeks.

At budged Complete: $\$ 102,199.79$.

Type Budget, the Special Allocation Fund (SAF) for Fiscal Year 2013.

Task Giver Department of Public Works, Mines and Energy West Southeast Molucas District and

Contractor is ' $\mathrm{X}$ ' company.

Indicator is the reference in analyzing the performance of the road project is based on Earned Value Management Concept includes three things:

1) Budgeted Cost for Work Scheduled (BCWS),

2) Actual Cost for Work Performed (ACWP) and

3) Budgeted Cost for Work Performed (BCWP ).

Of the three dimensions can be connected between the cost performance with time comes from

Cost calculation variant (SV) and

Schedule Varian (SV),

Cost Performance Index (CPI) and

Schedule Performanance Index (SPI). (Fleming and Koppelman, 1994).

\section{Iv. Earned Value Management on Controlling the Implementation of the Road Construction Project}

\section{A. Deviations of Project Schedule}

Based on secondary data, evaluation of overall performance on road projects Sp. Trans Yamdena Tumbur, deviation occurs when the implementation of the planning time. Deviations of time occurred during the 2 nd week and in the period week 13 until the project is completed ie until the 18th week, so the project has been delayed in total for approximately 14 working days, or about 2 weeks of the planned time is 16 weeks (Figure1). This could have an impact on project costs, especially indirect costs. The evaluation results are shown in Table 1 below. 
Proc. of The Third Intl. Conf. On Advances in Civil, Structural and Mechanical Engineering - ACSM 2015

Copyright $\odot$ Institute of Research Engineers and Doctors, USA .All rights reserved.

ISBN: 978-1-63248-083-5 doi: 10.15224/ 978-1-63248-083-5-61

TABLE 1. TIME PERFORMANCE EVALUATION RESULTS

\begin{tabular}{|c|c|c|c|c|c|c|c|c|}
\hline & \multirow[t]{2}{*}{ Parameter EVM } & \multicolumn{7}{|c|}{ Scheduled Planning, 120 work days /16 weeks } \\
\hline & & $\begin{array}{c}\text { Week } \\
\text { 1st }\end{array}$ & $\begin{array}{l}\text { Week } \\
\text { 2nd }\end{array}$ & $\begin{array}{l}\text { Week } \\
\text { 12th }\end{array}$ & $\begin{array}{l}\text { Week } \\
\text { 13th }\end{array}$ & $\begin{array}{l}\text { Week } \\
\text { 14th }\end{array}$ & $\begin{array}{l}\text { Week } \\
\text { 15th }\end{array}$ & $\begin{array}{l}\text { Week } \\
\text { 16th }\end{array}$ \\
\hline & Original Date (Week) & 16 & 16 & 16 & 16 & 16 & 16 & 16 \\
\hline & $\begin{array}{l}\text { Budget At } \\
\text { Complete (BAC) }\end{array}$ & $\$ 102,199.79$ & $\$ 102,199.79$ & $\$ 102,199.79$ & $\$ 102,199.79$ & $\$ 102,199.79$ & $\$ 102,199.79$ & $\$ 102,199.79$ \\
\hline & $\begin{array}{l}\text { Time used until } \\
\text { now (Week) }\end{array}$ & 1 & 2 & 12 & 13 & 14 & 15 & 16 \\
\hline A & Basic Parameter & & & & & & & \\
\hline & $\begin{array}{l}\text { Cummulative BCWS (Budget } \\
\text { Cost Work Scheduled) }\end{array}$ & $\$ 2,074.66$ & $\$ 4,200.41$ & $\$ 74,197.18$ & $\$ 83,497.36$ & $\$ 89,731.55$ & $\$ 95,965.74$ & $\$ 102,199.79$ \\
\hline & $\begin{array}{l}\text { Cummulative BCWP (Budget } \\
\text { Cost Work Performanced) }\end{array}$ & $\$ 0.00$ & $\$ 3,229.51$ & $\$ 78,090.99$ & $\$ 82,107.45$ & $\$ 86,123.90$ & $\$ 90,089.25$ & $\$ 94,064.82$ \\
\hline & $\begin{array}{l}\text { Cummulative ACWP (Actual } \\
\text { Cost Work Performanced) }\end{array}$ & $\$ 0.00$ & $\$ 1,858.73$ & $\$ 67,633.88$ & $\$ 72,037.92$ & $\$ 76,441.96$ & $\$ 80,846.00$ & $\$ 85,250.05$ \\
\hline B & Performanced Varians Project & & & & & & & \\
\hline & $\begin{array}{l}\text { SV = BCWP - BCWS } \\
\text { (Scheduled Varians) }\end{array}$ & $-\$ 2,074.66$ & $-\$ 970.90$ & $\$ 3,893.81$ & $-\$ 1,389.92$ & $-\$ 3,607.65$ & $-\$ 5,876.49$ & $-\$ 8,134.97$ \\
\hline & $\begin{array}{l}\mathrm{CV}=\mathrm{BCWP}-\mathrm{ACWP} \text { (Cost } \\
\text { Varians) }\end{array}$ & $\$ 0.00$ & $\$ 1,370.78$ & $\$ 10,457.12$ & $\$ 10,069.52$ & $\$ 9,681.93$ & $\$ 9,243.24$ & $\$ 8,814.77$ \\
\hline $\mathbf{C}$ & $\begin{array}{l}\text { Efficiency Index } \\
\text { Performanced of Project }\end{array}$ & & & & & & & \\
\hline & $\begin{array}{l}\text { SPI = BCWP/BCWS } \\
\text { (Scheduled Performanced } \\
\text { Index) }\end{array}$ & 0.00 & 0.77 & 1.05 & 0.98 & 0.96 & 0.94 & 0.92 \\
\hline & $\begin{array}{l}\mathrm{CPI}=\mathrm{BCWP} / \mathrm{ACWP}(\text { Cost } \\
\text { Performanced Index })\end{array}$ & 0.00 & 1.74 & 1.15 & 1.14 & 1.13 & 1.11 & 1.10 \\
\hline D & $\begin{array}{l}\text { Estimated Cost of Project } \\
\text { Forward }\end{array}$ & & & & & & & \\
\hline & $\begin{array}{l}\text { Estimation Cost Project To } \\
\text { Finish }\end{array}$ & & & & & & & \\
\hline & $\begin{array}{l}\text { B-ETC }=(\mathrm{BAC}-\mathrm{BCWP}) / \mathrm{CPI}- \\
\text { Budget Estimate To Complete }\end{array}$ & $\$ 0.00$ & $\$ 56,961.98$ & $\$ 20,880.40$ & $\$ 17,628.25$ & $\$ 14,268.66$ & $\$ 10,867.99$ & $\$ 7,372.64$ \\
\hline & $\begin{array}{l}\text { Estimation Total Cost Project } \\
\text { To Finish }\end{array}$ & & & & & & & \\
\hline & $\begin{array}{l}\text { B-EAC }=(A C W P n+B-E T C)- \\
\text { Budget Estimete At Complete }\end{array}$ & $\$ 0.00$ & $\$ 58,820.71$ & $\$ 88,514.28$ & $\$ 89,666.17$ & $\$ 90,710.62$ & $\$ 91,713.99$ & $\$ 92,622.69$ \\
\hline & $\begin{array}{l}\text { Varians Cost At Complete = } \\
(\mathrm{BAC}-\mathrm{B}-\mathrm{EAC})\end{array}$ & $\$ 0.00$ & $\$ 43,379.08$ & $\$ 13,685.51$ & $\$ 12,533.62$ & $\$ 11,489.17$ & $\$ 10,485.80$ & $\$ 9,577.10$ \\
\hline $\mathbf{E}$ & $\begin{array}{l}\text { Estimated Scheduled of } \\
\text { Project Forward }\end{array}$ & & & & & & & \\
\hline & $\begin{array}{l}\text { Estimation Scheduled Project } \\
\text { To Finish }\end{array}$ & & & & & & & \\
\hline & $\begin{array}{l}\text { S-ETC }=(\text { OD-Elapsed } \\
\text { time }) / \text { SPI - (Weeks })\end{array}$ & 0.00 & 18.21 & 3.80 & 3.05 & 2.08 & 1.07 & 0.00 \\
\hline & $\begin{array}{l}\text { Scheduled Estimate To } \\
\text { Complete }\end{array}$ & & & & & & & \\
\hline & $\begin{array}{l}\text { Estimation Total Scheduled } \\
\text { Project To Finish }\end{array}$ & & & & & & & \\
\hline & $\begin{array}{l}\text { S-EAC }=(\text { Elapsed time }+ \text { S- } \\
\text { ETC })-(\text { Weeks })\end{array}$ & 0.00 & 20.21 & 15.80 & 16.05 & 16.08 & 16.07 & 16.00 \\
\hline & $\begin{array}{l}\text { Scheduled Estimate At } \\
\text { Complete }\end{array}$ & & & & & & & \\
\hline & $\begin{array}{l}\text { Varians Schedule At Complete } \\
\text { (Weeks) }\end{array}$ & 16 & 4.21 & 0.20 & 0.05 & 0.08 & 0.07 & 0.00 \\
\hline
\end{tabular}


Proc. of The Third Intl. Conf. On Advances in Civil, Structural and Mechanical Engineering - ACSM 2015

Copyright $(\odot$ Institute of Research Engineers and Doctors, USA .All rights reserved.

ISBN: 978-1-63248-083-5 doi: 10.15224/ 978-1-63248-083-5-61

\section{B. Cause of occurence Deviations Project Schedule}

Causes delay in project based on primary data collected in Table 2 below:

TABLE 2. CAUSES DELAY

\begin{tabular}{|c|c|c|c|c|}
\hline No & $\begin{array}{c}\text { Week } \\
\text { to }\end{array}$ & $\begin{array}{c}\text { Causes } \\
\text { of deviation }\end{array}$ & $\begin{array}{c}\text { Scope of } \\
\text { work }\end{array}$ & Proposed Control \\
\hline 1. & 2nd & Process redesign & Embankment & $\begin{array}{l}\text { Accelerate or process } \\
\text { redesign before the } \\
\text { project is implemented so } \\
\text { as not to hamper the } \\
\text { implementation process } \\
\text { that has been planned. On } \\
\text { this analysis conducted } \\
\text { for one week accelerated } \\
\text { the shift time to redesign. }\end{array}$ \\
\hline 2. & 13th & $\begin{array}{l}\text { Lessening of } \\
\text { manpower,the } \\
\text { number } \\
\text { workers who have } \\
\text { competence very } \\
\text { limited, and late } \\
\text { allocation of } \\
\text { material and } \\
\text { equipment }\end{array}$ & $\begin{array}{l}\text { Primecoat / } \\
\text { tackcoat and } \\
\text { Macadam } \\
\text { Penetration }\end{array}$ & $\begin{array}{l}\text { Adding the amount of } \\
\text { manpower began at week } \\
12 \text {, while increasing the } \\
\text { number of labor force is } \\
\text { directly proportional to } \\
\text { the addition of indirect } \\
\text { costs. Procurement of } \\
\text { materials and equipment } \\
\text { must be on schedule plan }\end{array}$ \\
\hline
\end{tabular}

\section{c. Control of the time and cost of the project}

Adding manpower, starting week 12th based on the analysis as follows:

\begin{tabular}{|c|c|c|c|c|}
\hline \multicolumn{2}{|r|}{ I YSIS $\quad O F$} & \multicolumn{2}{|c|}{ PRODUCTIVIT } & \\
\hline \multicolumn{5}{|c|}{ MANPOWER(MP)AT MACADAM PENETRATION } \\
\hline \multicolumn{5}{|c|}{$\begin{array}{l}\text { Analysis of Productivity of manpower at } \\
\text { Macadam Penetration }\end{array}$} \\
\hline 1 & The volume of the items Late Work & $=$ & 302,83 & $\mathrm{~m} 3$ \\
\hline & The total duration of which has been & & & \\
\hline 2 & delayed & $=$ & 7 & week \\
\hline 3 & $\begin{array}{l}\text { The total number of manpower } \\
\text { earlier in the week } 12 \text { th until } 18 \text { th }\end{array}$ & $=$ & 20 & (MP) \\
\hline \multirow[t]{3}{*}{4} & & $=$ & 43.26 & $\begin{array}{l}\text { m3/ } \\
\text { week }\end{array}$ \\
\hline & Manpower productivity & $=$ & 7.21 & $\begin{array}{l}\text { m3/day } \\
\text { m3/day/ }\end{array}$ \\
\hline & & $=$ & 0.36 & MP \\
\hline 5 & $\begin{array}{l}\text { The total duration of the estimated } \\
\text { after controlling }\end{array}$ & $=$ & 3.00 & week \\
\hline 6 & Time for 1 manpower & $=$ & 840 & day \\
\hline \multirow[t]{2}{*}{7} & Plan to increase the total number of & $=$ & 46.6 & MP/day \\
\hline & manpower & $=$ & 47 & MP/day \\
\hline \multirow[t]{2}{*}{8} & $\begin{array}{l}\text { The actual number of MP began } \\
\text { weeks } 12 \text { th }\end{array}$ & $=$ & 20 & MP \\
\hline & Salary of MP & $=$ & $\$ 4,412$ & MP \\
\hline 9 & Schedule Control & & & \\
\hline \multirow{4}{*}{10} & $\begin{array}{l}\text { The total number of manpower } \\
\text { weeks } 12 \text { th } \\
\text { Actual Cost : The addition of MP }\end{array}$ & $=$ & 47.00 & MP \\
\hline & costs & $=$ & $\$ 119.12$ & day \\
\hline & The addition of MP costs & $=$ & $\$ 714.71$ & week \\
\hline & $\begin{array}{l}\text { The addition of equipment costs } \\
\text { TOTAL }\end{array}$ & $\begin{array}{l}= \\
=\end{array}$ & $\begin{array}{l}\$ 2,202.02 \\
\$ 2.916 .73\end{array}$ & $\begin{array}{l}\text { week } \\
\text { week }\end{array}$ \\
\hline
\end{tabular}

Table 4. COST CALCULATION RESULTS BEFORE AND AFTER CONTROL

\begin{tabular}{|l|c|c|}
\hline Parameter & Before Control & After Control \\
\hline ACWP & $\$ 94,058.13$ & $\$ 84,134$ \\
\hline Saving (\%) & - & 10,55 \\
\hline Profit (\%) & 7,97 & 17,67 \\
\hline
\end{tabular}

\section{Results Control of Time and Cost Performance Project}

Control is done by using EVM, beginning at week 2nd and at week 12th until the project can be completed. Results of the evaluation time control at week 2 th clearly visible performance of the project time better and increase of performance has been realized previously, where the index performance when SPI and cost CPI> 1 and estimate the approximate time is much faster around 8 weeks to the actual cost more lower than the cost of the plan.

\section{TABLE 5. RESULTS CONTROL OF TIME AND COST} PERFORMANCE PROJECT

\begin{tabular}{|c|c|c|c|c|c|c|}
\hline & \multirow{2}{*}{$\begin{array}{c}\text { Parameter } \\
\text { EVM }\end{array}$} & \multicolumn{5}{|c|}{ Scheduled } \\
\hline & & $\begin{array}{c}\text { Week } \\
1\end{array}$ & $\begin{array}{c}\text { Week } \\
2\end{array}$ & $\begin{array}{l}\text { Week } \\
12\end{array}$ & $\begin{array}{c}\text { Week } \\
13\end{array}$ & $\begin{array}{c}\text { Week } \\
14\end{array}$ \\
\hline & Original Date (Week) & 16 & 16 & 16 & 16 & 16 \\
\hline & $\begin{array}{l}\text { Budget At Complete } \\
\text { (BAC) }\end{array}$ & $\begin{array}{c}\$ 102,199 . \\
79\end{array}$ & $\begin{array}{c}\$ 102,199 . \\
79\end{array}$ & $\begin{array}{l}\$ 102,199 . \\
79\end{array}$ & $\begin{array}{l}\$ 102,199 . \\
79\end{array}$ & $\begin{array}{c}\$ 102,199 . \\
79\end{array}$ \\
\hline & $\begin{array}{l}\text { Time used until now } \\
\text { (Week) }\end{array}$ & 1 & 2 & 12 & 13 & 14 \\
\hline $\mathbf{A}$ & Basic Parameter & & & & & \\
\hline & $\begin{array}{l}\text { Cummulative BCWS } \\
\text { (Budget Cost Work } \\
\text { Scheduled) }\end{array}$ & $\begin{array}{l}\$ 2,074 . \\
66\end{array}$ & $\begin{array}{l}\$ 4,200 . \\
41\end{array}$ & $\begin{array}{c}\$ 74,197 . \\
18\end{array}$ & $\begin{array}{l}\$ 83,497 . \\
36\end{array}$ & $\begin{array}{l}\$ 89,731 . \\
55\end{array}$ \\
\hline & $\begin{array}{l}\text { Cummulative BCWP } \\
\text { (Budget Cost Work } \\
\text { Performanced) }\end{array}$ & $\begin{array}{l}\$ 3,229 . \\
51\end{array}$ & $\begin{array}{l}\$ 9,668 . \\
24\end{array}$ & $\begin{array}{l}\$ 93,451 . \\
\quad 62\end{array}$ & $\begin{array}{c}\$ 101,218 . \\
81\end{array}$ & $\begin{array}{l}\$ 102,199 . \\
79\end{array}$ \\
\hline & $\begin{array}{l}\text { Cummulative ACWP } \\
\text { (Actual Cost Work } \\
\text { Performanced) }\end{array}$ & $\$ 1,858.73$ & $\$ 3,717.47$ & $\$ 69,492.61$ & $\$ 74,611.52$ & $\$ 79,730.43$ \\
\hline B & $\begin{array}{l}\text { Performanced Varians } \\
\text { Project }\end{array}$ & & & & & \\
\hline & $\begin{array}{l}\text { SV = BCWP - BCWS } \\
\text { (Scheduled Varians) }\end{array}$ & $\$ 1,154.86$ & $\$ 5,467.82$ & $\$ 19,254.44$ & $\$ 17,721.44$ & $\$ 12,468.24$ \\
\hline & $\begin{array}{l}\mathrm{CV}=\mathrm{BCWP}-\mathrm{ACWP} \\
(\text { Cost Varians) }\end{array}$ & $\$ 1,370.78$ & $\$ 5,950.77$ & $\$ 23,959.01$ & $\$ 26,607.28$ & $\$ 22,469.36$ \\
\hline C & $\begin{array}{l}\text { Efficiency Index } \\
\text { Performanced of } \\
\text { Project }\end{array}$ & & & & & \\
\hline & $\begin{array}{l}\text { SPI = BCWP/BCWS } \\
\text { (Scheduled } \\
\text { Performanced Index) }\end{array}$ & $\$ 1.56$ & $\$ 2.30$ & $\$ 1.26$ & $\$ 1.21$ & $\$ 1.14$ \\
\hline & $\begin{array}{l}\text { CPI = BCWP/ACWP } \\
\text { (Cost Performanced } \\
\text { Index) }\end{array}$ & $\$ 0.00$ & $\$ 2.60$ & $\$ 1.34$ & $\$ 1.36$ & $\$ 1.28$ \\
\hline D & $\begin{array}{l}\text { Estimated Cost of } \\
\text { Project Forward }\end{array}$ & & & & & \\
\hline & $\begin{array}{l}\text { Estimation Cost } \\
\text { Project To Finish }\end{array}$ & & & & & \\
\hline & $\begin{array}{l}\text { B-ETC }=(\mathrm{BAC}- \\
\text { BCWP } / \text { CPI - Budget } \\
\text { Estimate To Complete }\end{array}$ & $\$ 0.00$ & $\$ 35,578.69$ & $\$ 6,505.32$ & $\$ 723.11$ & $\$ 0.00$ \\
\hline & $\begin{array}{l}\text { Estimation Total Cost } \\
\text { Project To Finish }\end{array}$ & & & & & \\
\hline & $\begin{array}{l}\text { B-EAC }=\left(A C W P^{n}+B-\right. \\
\text { ETC }) \text { - Budget Estimate } \\
\text { At Complete }\end{array}$ & $\$ 0.00$ & $\$ 39,296.16$ & $\$ 75,997.94$ & $\$ 75,334.64$ & $\$ 79,730.43$ \\
\hline & $\begin{array}{l}\text { Varians Cost At } \\
\text { Complete = (BAC - B- } \\
\text { EAC })\end{array}$ & $\$ 0.00$ & $\$ 62,903.63$ & $\$ 26,201.85$ & $\$ 26,865.15$ & $\$ 22,469.36$ \\
\hline
\end{tabular}


Proc. of The Third Intl. Conf. On Advances in Civil, Structural and Mechanical Engineering - ACSM 2015

Copyright $(\odot$ Institute of Research Engineers and Doctors, USA .All rights reserved.

ISBN: 978-1-63248-083-5 doi: 10.15224/ 978-1-63248-083-5-61

TABLE 5. CONTINUATION....

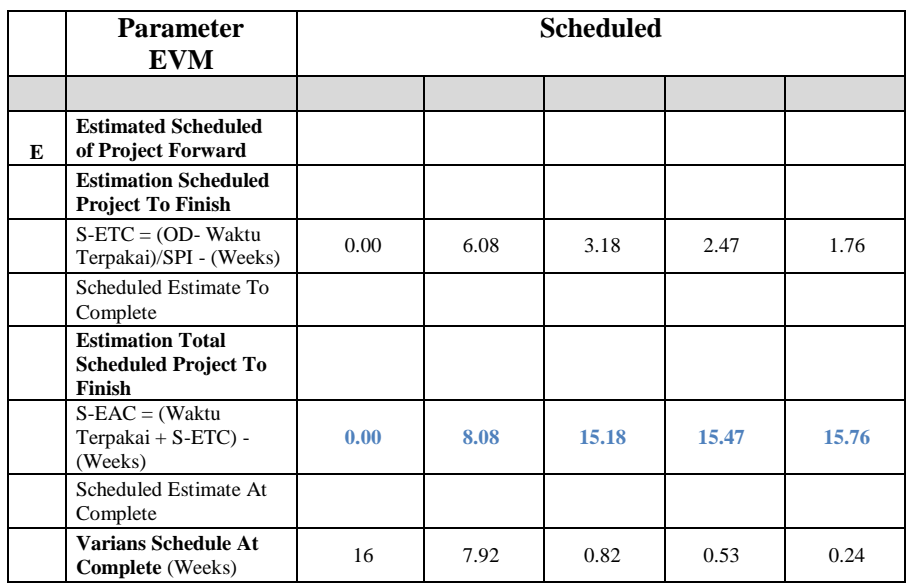

Results of the performance control the time and cost of the overall project with methods of Earned Value Management $(\mathrm{EVM})$ is shown in Figure 1.

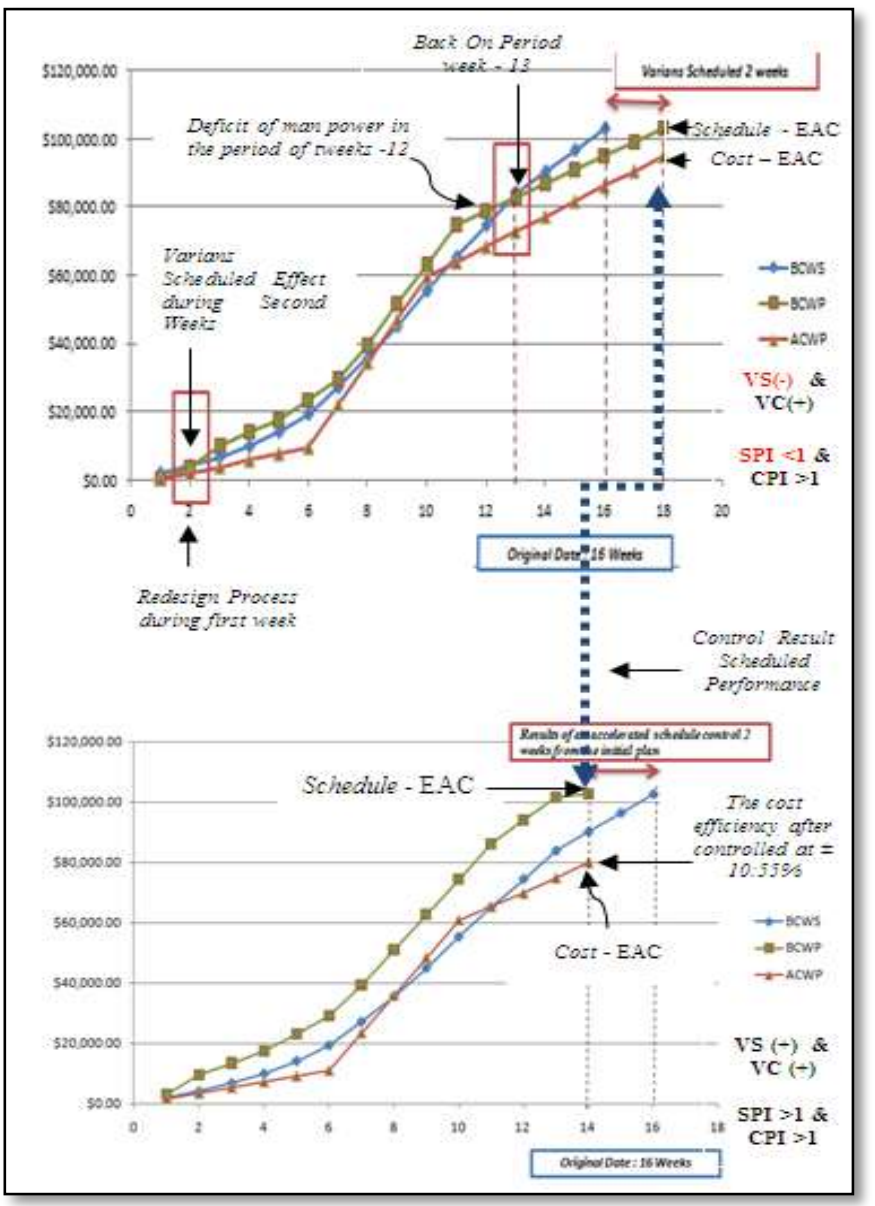

Figure 1. Results Comparison Project Time and Costs Performance Before And After Controled With EVM Method

\section{v. Recommendation}

The contractors should use evaluation methods Earned Value Management (EVM) in controlling the performance of the project since early so that they can determine how much the performance in terms of time and or cost and also be aware of irregularities that have and will occur during the life cycle project.

\section{Acknowledgement}

This research was supported by the Ministry of Research, Technology and Higher Education of Indonesia. Therefore, the authors are grateful and thank you very much.

\section{References}

[1] Ahuja, H., Dozki, S.P., Abourizk S. M : “ Project Management Techniques in Planning and Controlling Construction Project" John Willey \& Sons. 1994

[2] Flemming, Q. W., Koppelman, J. M : "The Essence and Evoluation of Earned Value", AACE Transaction. 1994

[3] James Thoengsal : Pengendalian Waktu dan Biaya dengan Menggunakan Metode EVM". Thesis. Civil Engineering Dept. Universitas Kristen Indonesia Paulus - Makassar- Indonesia. 2015

[4] Jefferson Science Associates, LLC.:"Earned Value Management System" GuidelinesComplaince.www.jlab,org/div.dept/directorate/proj

[5] Latupeirissa, J. E and Irwan Lie (2015): "The Influence of Risk Factor toward the Time of Implementation The Road and Bridge Projects". International Journal of Civil\&Sructural Engineering, Volume 2, Issue 2. Page 36-40. 19 October 2015

[6] Latupeirissa, J. E and Jonie Tanijaya : "Evaluasi Kinerja Waktu Pelaksanaan Proyek Jalan dan Jembatan di Indonesia Timur", Seminar Nasional Teknik Sipil ke 8 (KonTekS8), ITENAS Bandung- Indonesia 16-17 October 2014

[7] National Defense Industrial Association (NDIA) Program Management Systems Committee (PMSC) ANSI/EIA-748-A : Standard for Earned Value Management Systems Intent Guide. National Defense Industrial Association . Januari 2006

[8] Pujoartanto, N : "Kajian Potensi Pengembangan Earned Value Management System (EVMS) Pada Sistem Akuntansi Biaya Kontraktor Kecil” Thesis. Civil Engineering Dept. ITB . Bandung-Indonesia. 2008

[9] Risti Garsia Sari : "Penerapan Metode Analisis Performansi Pada Perancangan Sistem Pengendalian Proyek"Thesis. Civil Engineering Dept. Petra University, Surabaya - Indonesia. 2009

[10] Soemardi, B.W., Wirahadikusumah, R.D., Abduh, M : "Konsep Earned Value untuk Pengelolaan Proyek Konstruksi. Jurnal Ilmiah. BandungIndonesia.2006

[11] Susanto, F. K : "Usulan Sistem Pengendalian Biaya Proyek (Studi Kasus: Kontraktor A, B, C di Surabaya", Thesis. Civil Engineering Dept. Petra University Surabaya - Indonesia.2008

[12] Tayl. D. R :" Kajian Penerapan Nilai Hasil Pada Pelaksanaan Proyek Konstruksi Jalan". Thesis. Civil Engineering Dept. UNiversitas Kristen Indonesia Paulus. 2014

About Author (s):

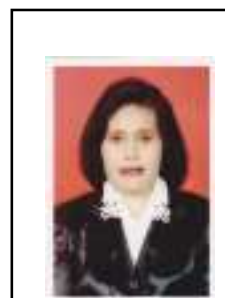

Dr.Josefine

Ernestine

Latupeirissa
Earned Value Management is a technique and method of cost and schedule control who used to measure the performance of integrated cost and schedule that can quickly reveal deviation. In practice, Earned Value Management incorporate and link the elements of the budget, expenses, schedule, score result, the scope of work and implementing organizations 